\title{
SUSPECTED ENDEMIC SYPHILIS (TREPONARID) IN SIXTEENTH-CENTURY NORWAY
}

\author{
by \\ TREVOR ANDERSON,* CAROLINE ARCINI,* SVEIN ANDA, $\dagger$ \\ ÅSE TANGERUD, $\dagger$ AND GUNVOR ROBERTSEN†
}

A study of ninety-five skeletons excavated from the later medieval and early Renaissance levels of a cemetery in Trondheim has revealed bone changes compatible with a treponemal infection which is suspected to be endemic syphilis. This is an important discovery as it is the earliest pathological evidence, so far reported, for this disease in Norway. The diagnosis is supported by X-ray findings.
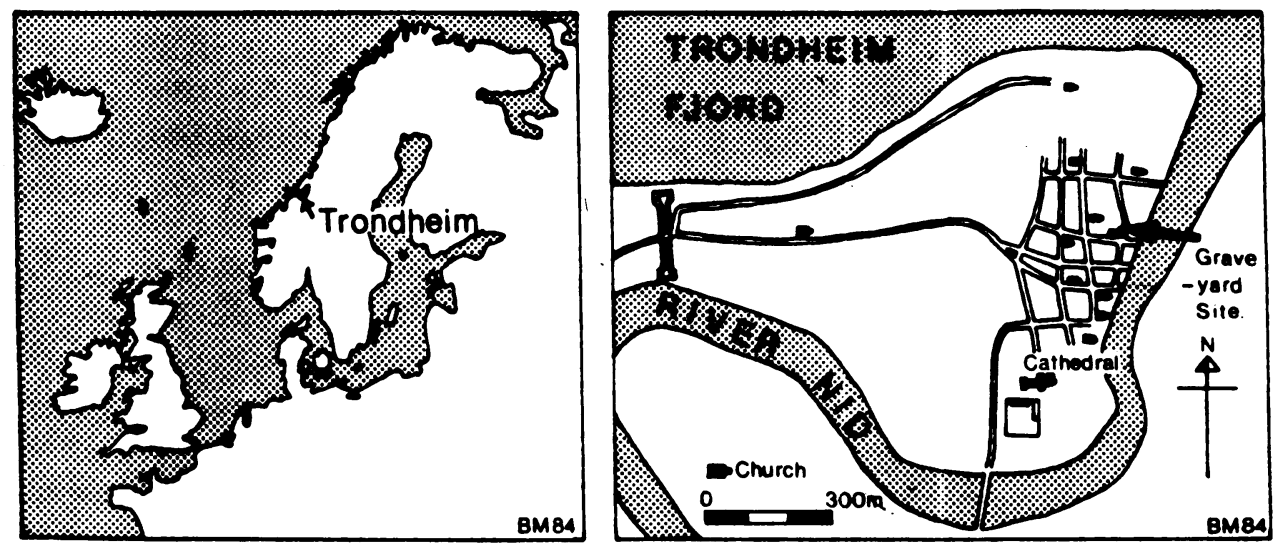

Figure 1 Location map of medieval Trondheim.

The town of Trondheim, situated on the west coast of Norway (fig. 1), has been, since 1971, the centre for a series of excavations directed by Clifford Long and Erik Jondell on behalf of Riksantikvaren. In June 1984, a two-year project began on the site of the medieval Franciscan (Greyfriars) church, parts of which are still visible today.

\footnotetext{
*Trevor Anderson and Caroline Arcini, Riksantikvaren (The Historical Monuments Office), Trondheim, Norway.

tSvein Anda, MD, Åse Tangerud, MD, and Gunvor Robertsen, Department of Radiology, University Hospital, Trondheim.
} 


\section{T. Anderson, C. Arcini, S. Anda, A. Tangerud, and G. Robertsen}

This work is being carried out in advance of extensions to the public library and has been made possible by funds from Trondheim Council. The excavation of the cemetery, supervised by Hans Göthberg, is still in progress, and what follows is a preliminary report based on the skeletal material from the 1984 season. The purpose of this paper is to publish evidence for what we consider to be endemic syphilis in sixteenth-century Trondheim, to comment on the standard of living of the town's inhabitants, and also to discuss possible methods by which syphilis could have spread through Norway.

MATERIAL

We have based our conclusions on the following observations and X-ray findings (table 1):

Skeleton 5

N 80662

Age:17-20 Sex:Male Height:176 cm

State of preservation : Very good. All bones present, except for some of the hand and feet phalanges and the sternum. The skull, scapulae, vertebrae, left clavicula, and the proximal end of the left femur are fragmentary.

Teeth: $\quad 42$ lost post mortem. The teeth are unworn and well-preserved.

Tibiae: Exhibit symmetrical marked bilateral swelling and striation of the diaphyses, more severe towards the middle of the shafts. The medial surface and the anterior margin are mainly affected, with consequent rounding of the latter. (Plate 1 )

$\mathrm{X}$-ray findings: Show cortical thickening and a distinct border between the original normal corticalis and the periosteal new bone formation. The medullary cavity appears normal. (Plates 2 and 3)

Ulnae: Right, normal. Left, slight swelling restricted to the posterior surface of the proximal diaphysis.

$\mathrm{X}$-ray findings: Confirm this swelling as being due to new bone formation.

Skeleton 22

$$
\text { N } 80679
$$

Age:35-45 Sex:Female?Height: $164 \mathrm{~cm}$

State of preservation: Excellent. Scapulae and pelvis are broken, maxilla is fragmentary.

Teeth: $\quad 11$ and 42 lost post mortem. 31, 32 and 33 have been lost in vivo. The teeth are heavily worn.

Tibiae: Exhibit bilateral swelling and striation of the diaphyses, more marked towards the middle of the shafts. Left, confined to the medial surface. Right, slightly more advanced with localized swelling also on the lateral surface of the central diaphysis. Anterior border of the tibiae still distinct and there is no bowing of the shafts. (Plate 4)

X-ray findings: Show relative symmetric thickening in the diaphyseal corticalis of the tibiae. More marked on the right, which shows irregularities of the endosteal surface as well as small lytic areas of 


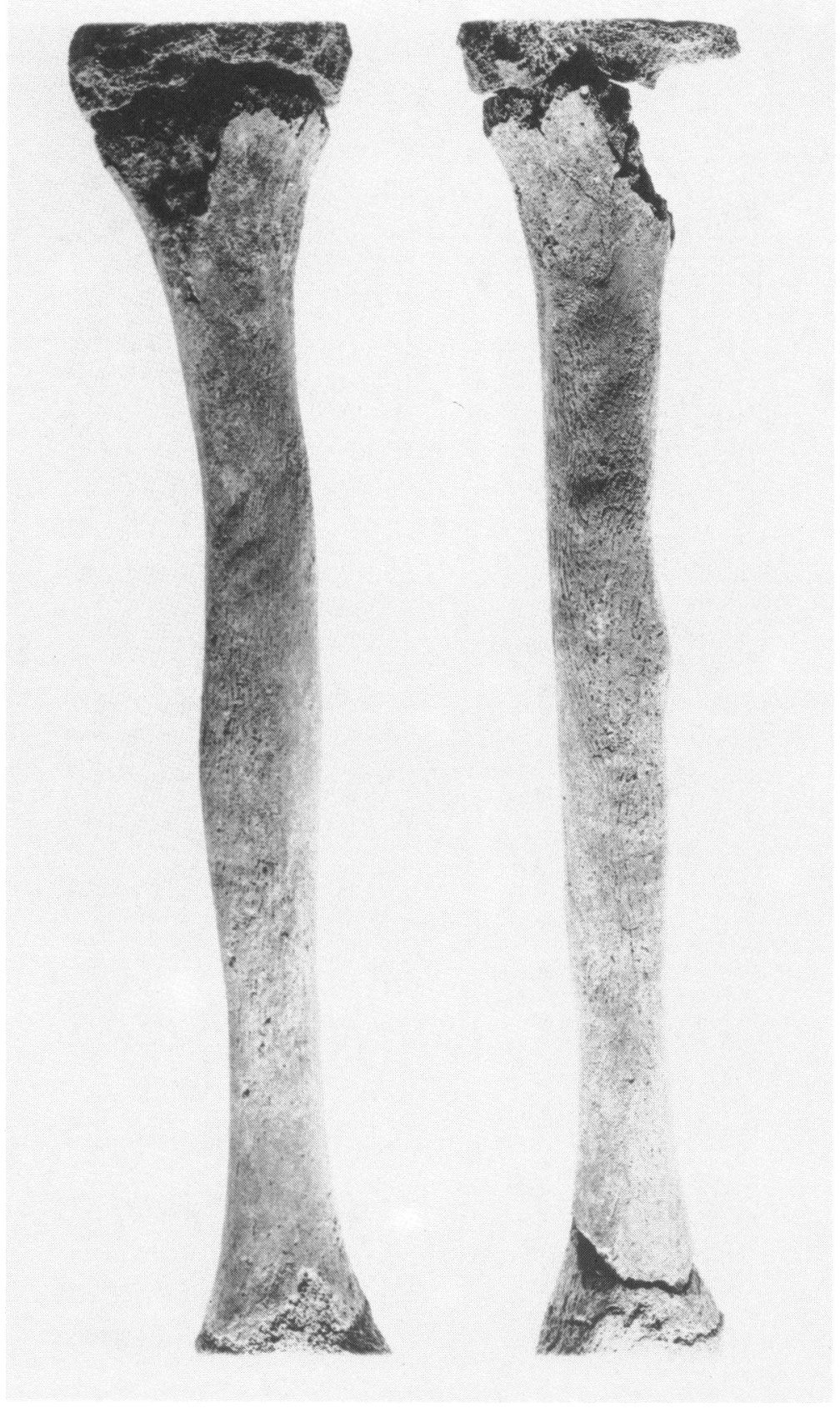

Plate 1a Frontal view of the tibiae of Sk 5. 


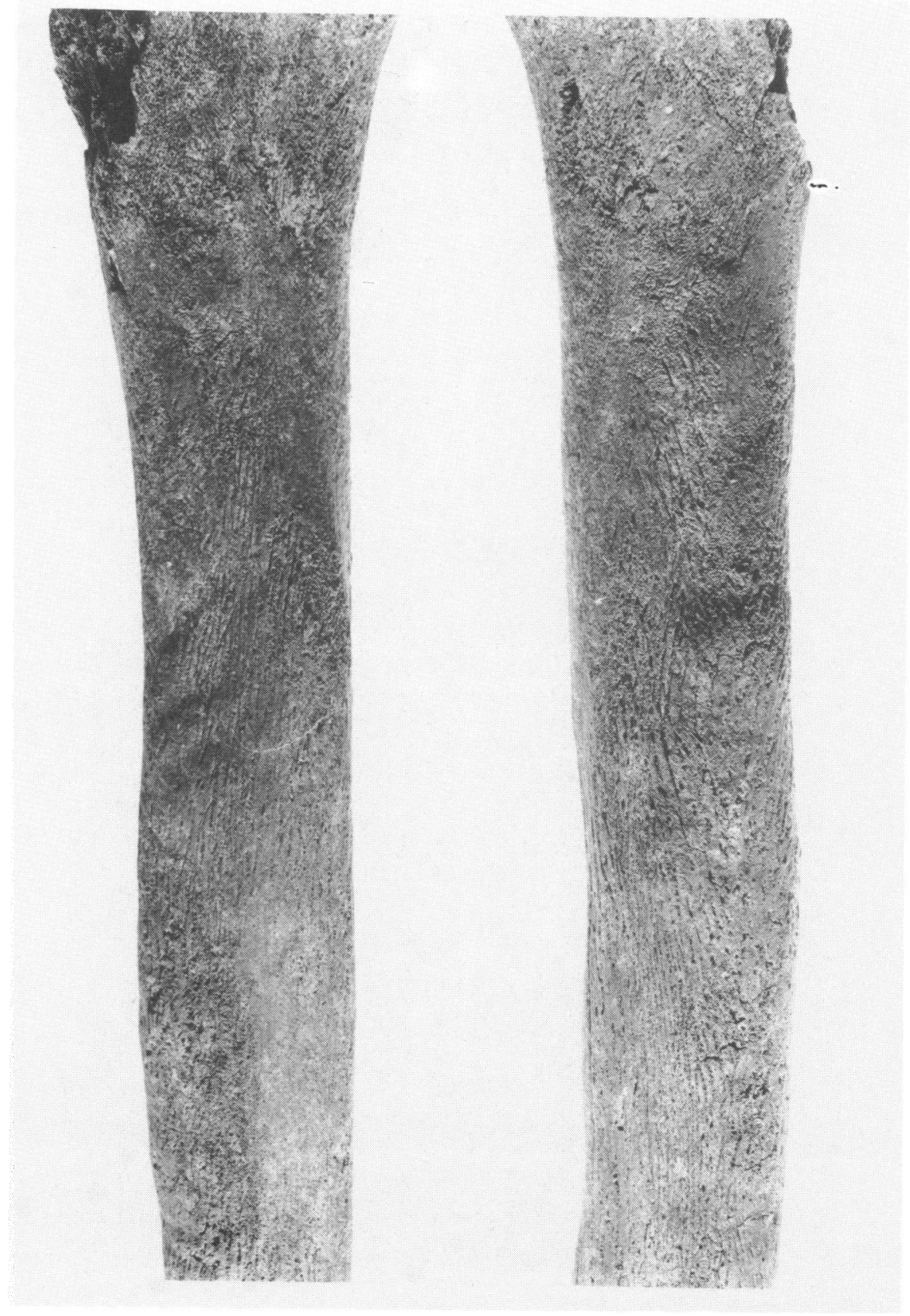

Plate $1 b$ Enlarged medial surface of tibiae. 


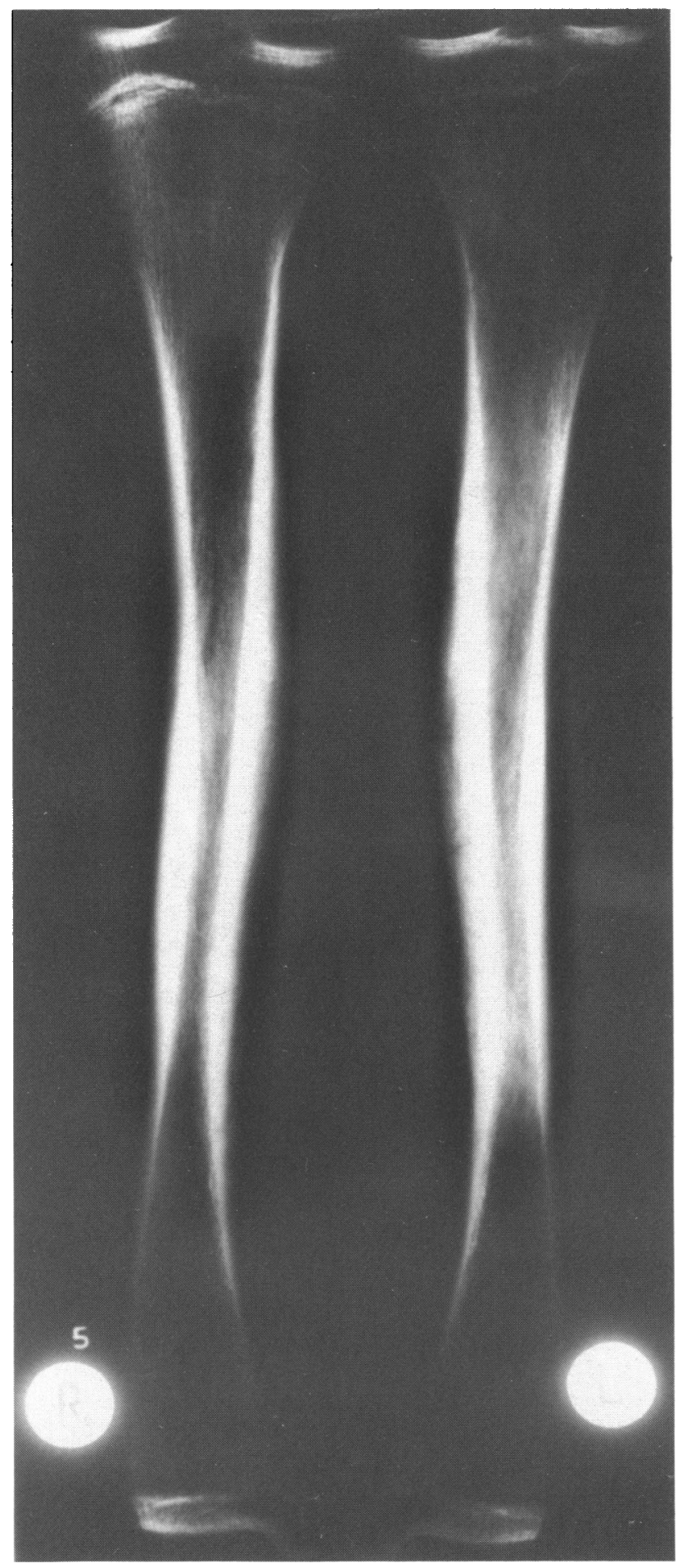

Plate 2 Frontal X-ray projection of tibiae Sk 5. 


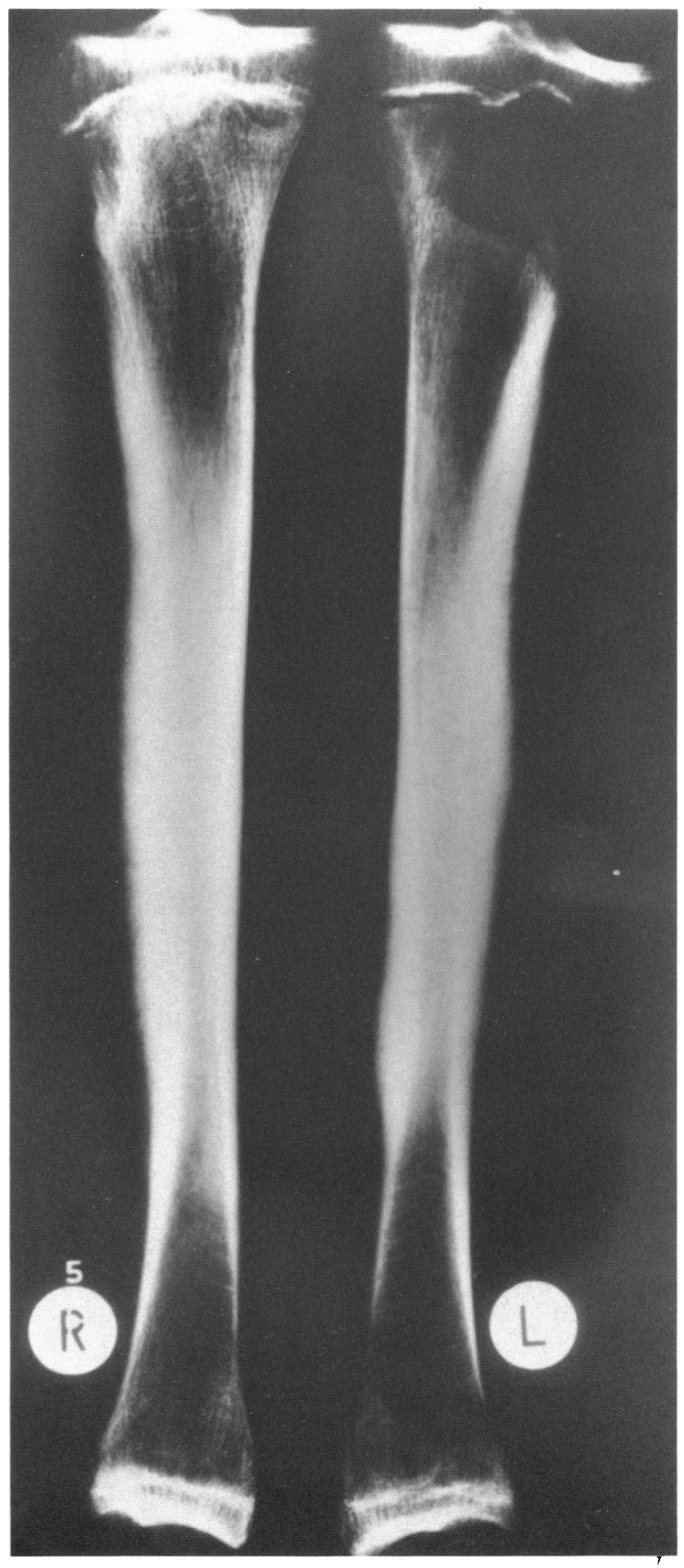

Plate 3 Lateral X-ray projection of tibiae Sk 5. 


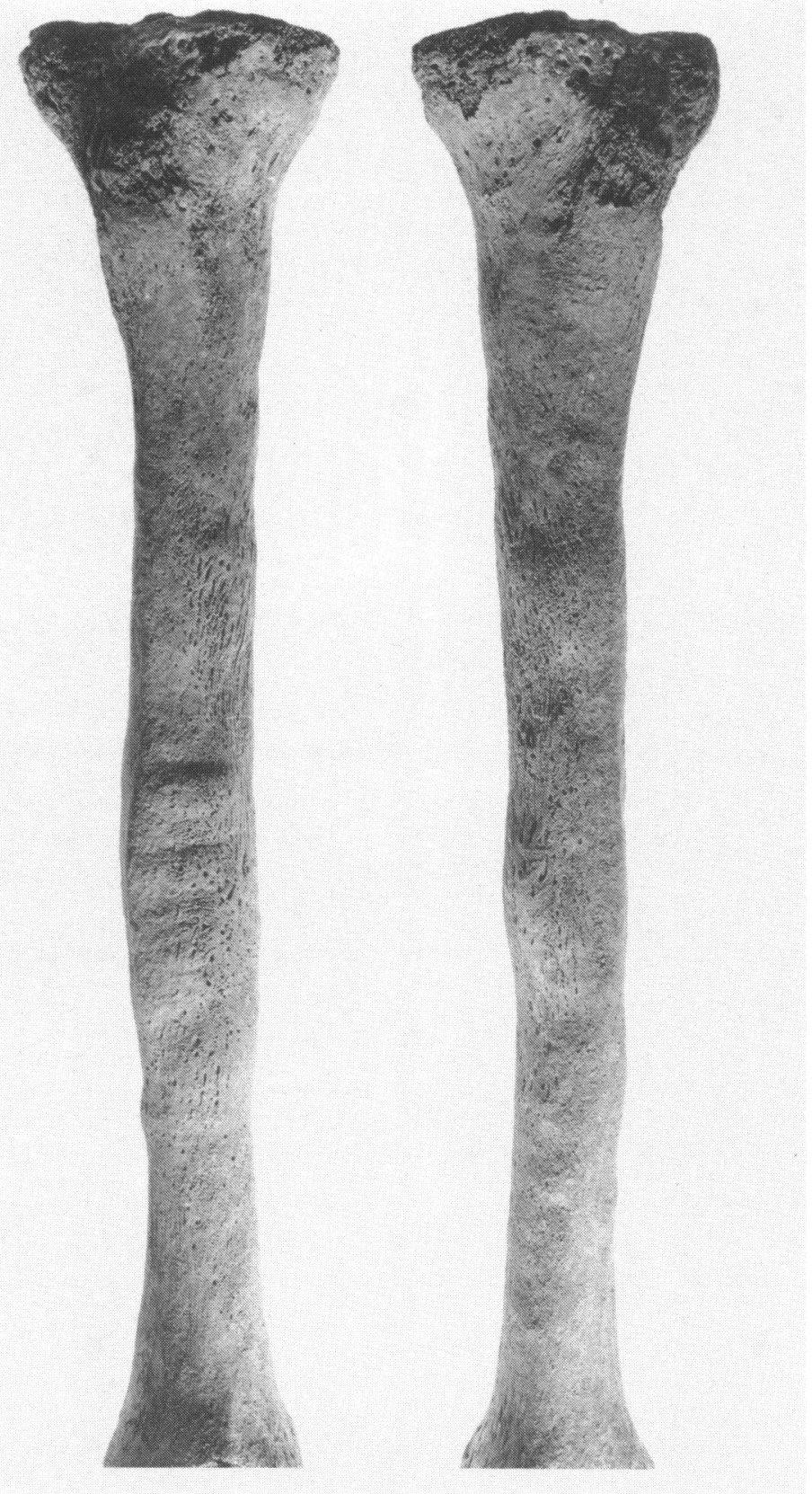

Plate $4 a$ Frontal view of the tibiae of Sk 22. 

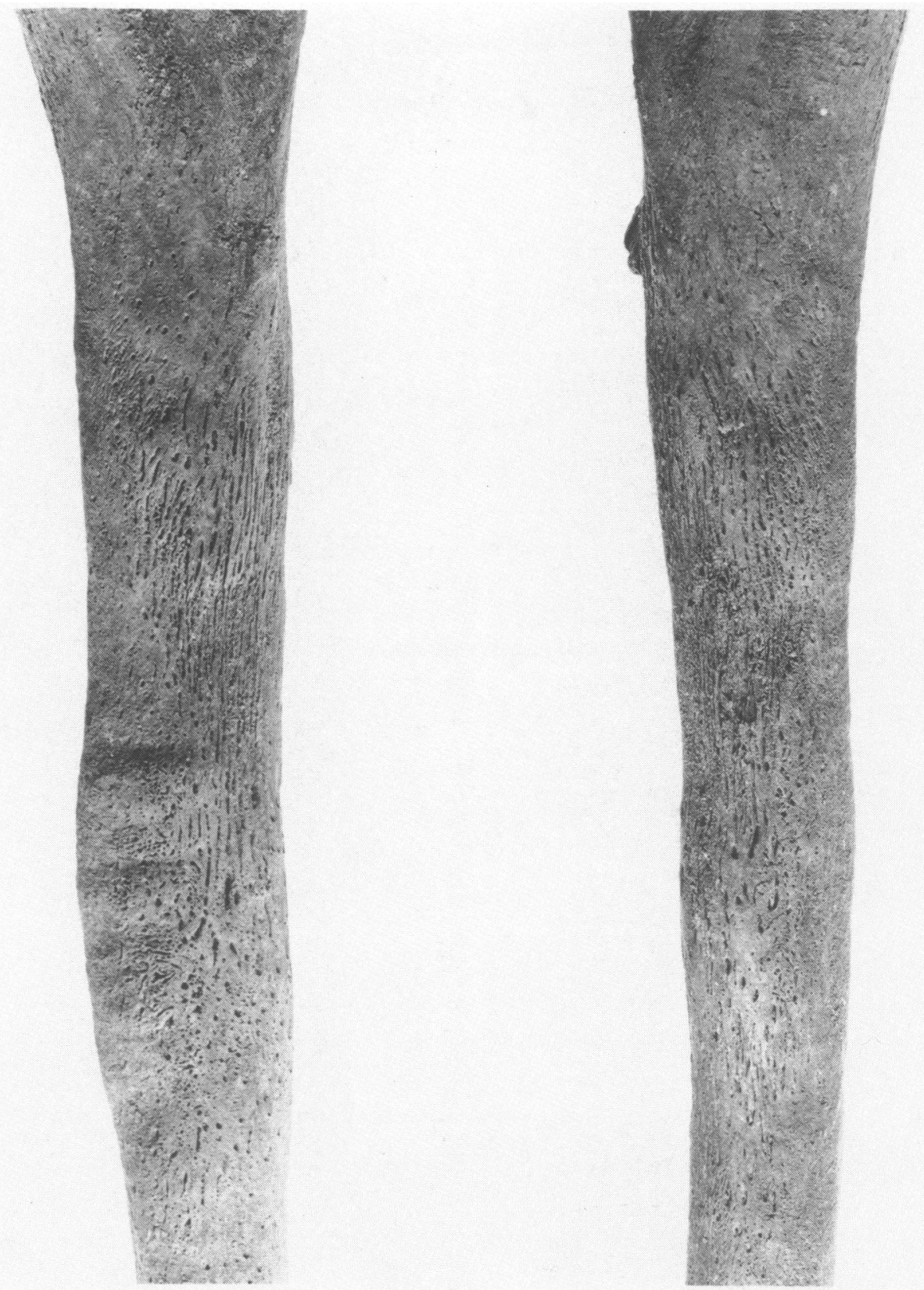

Plate $4 b$ Enlarged medial surface of tibiae. 


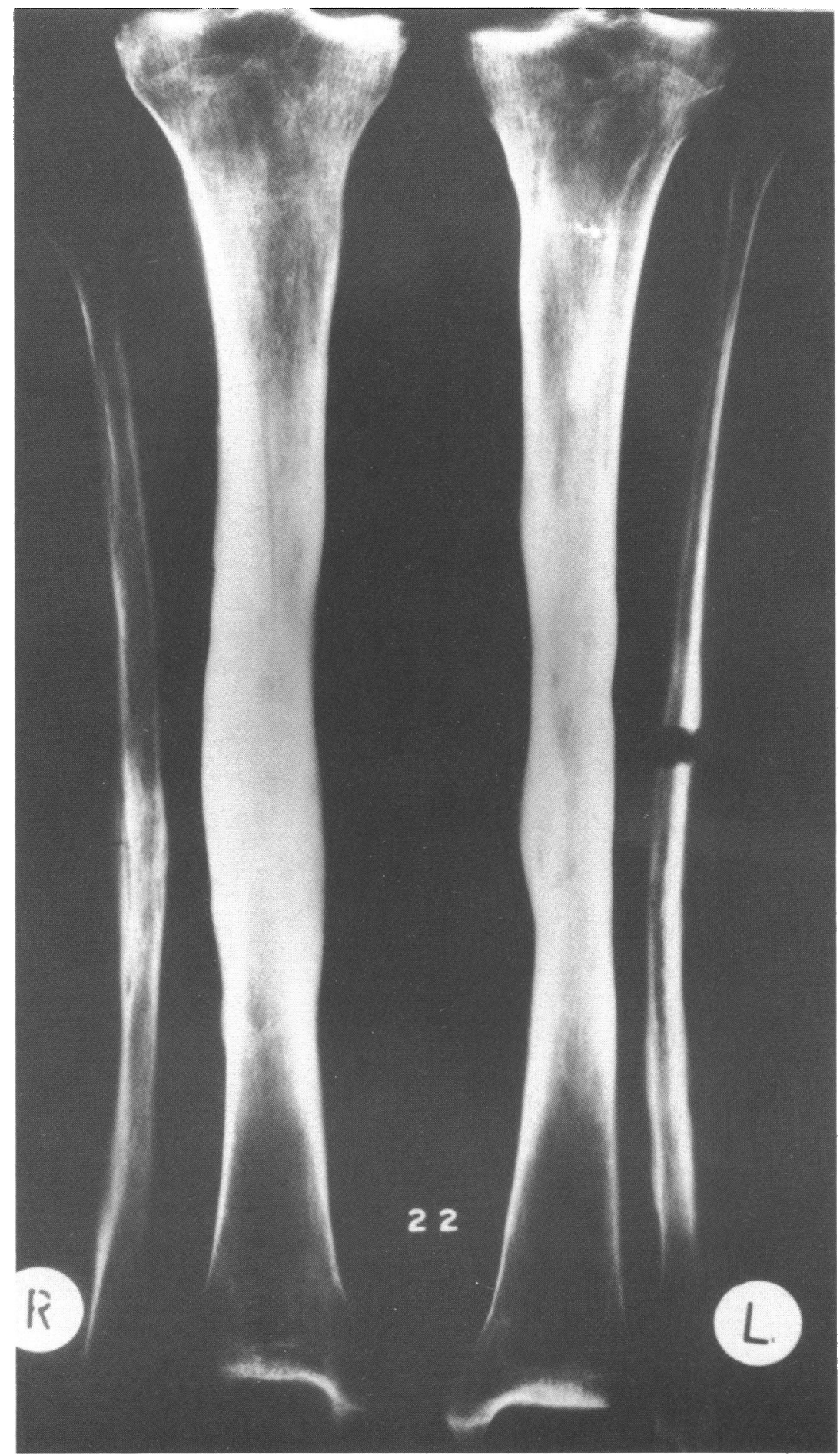

Plate 5 Frontal X-ray projection of tibiae Sk 22. 


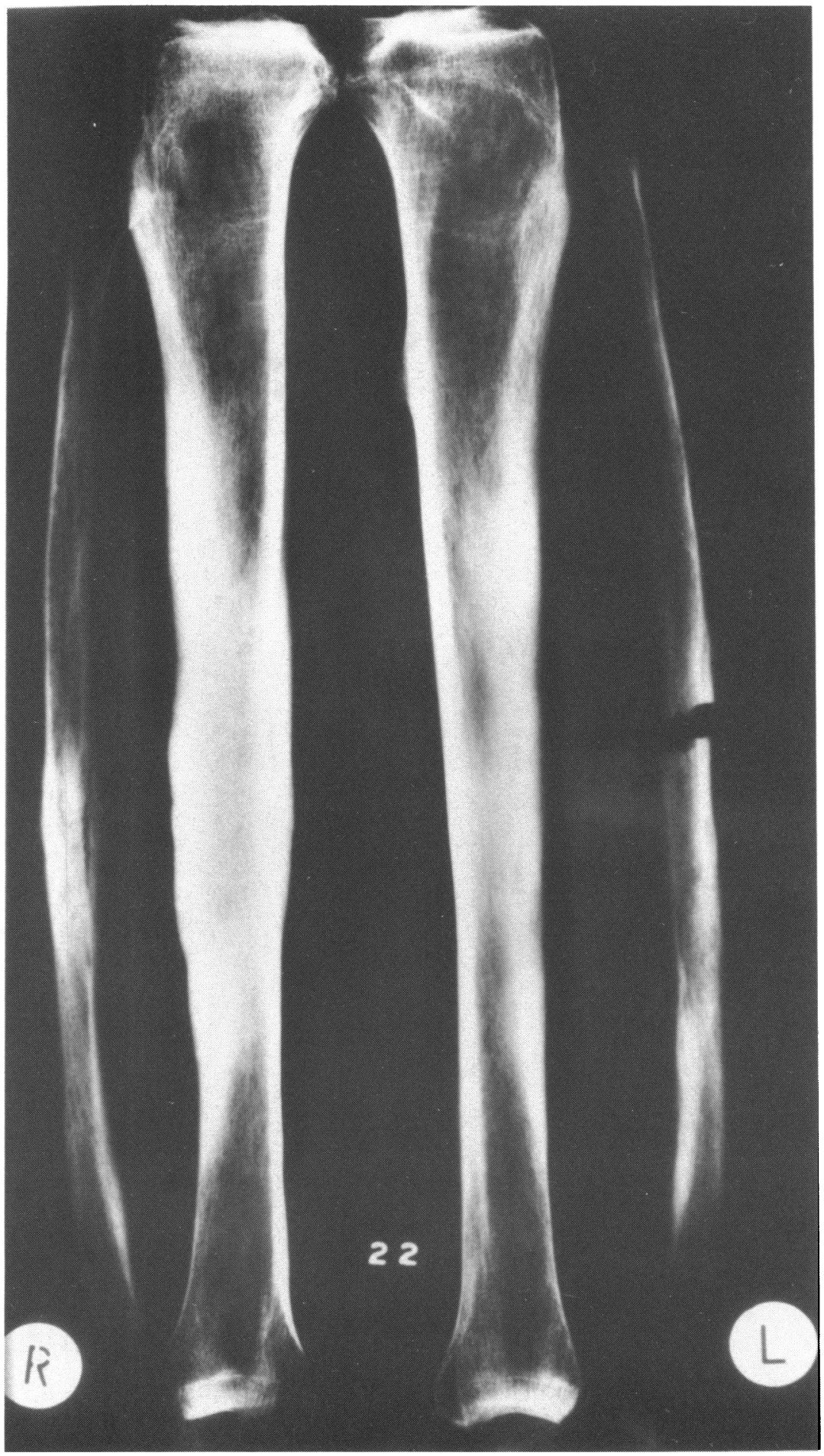

Plate 6 Lateral X-ray projection of tibiae Sk 22. 


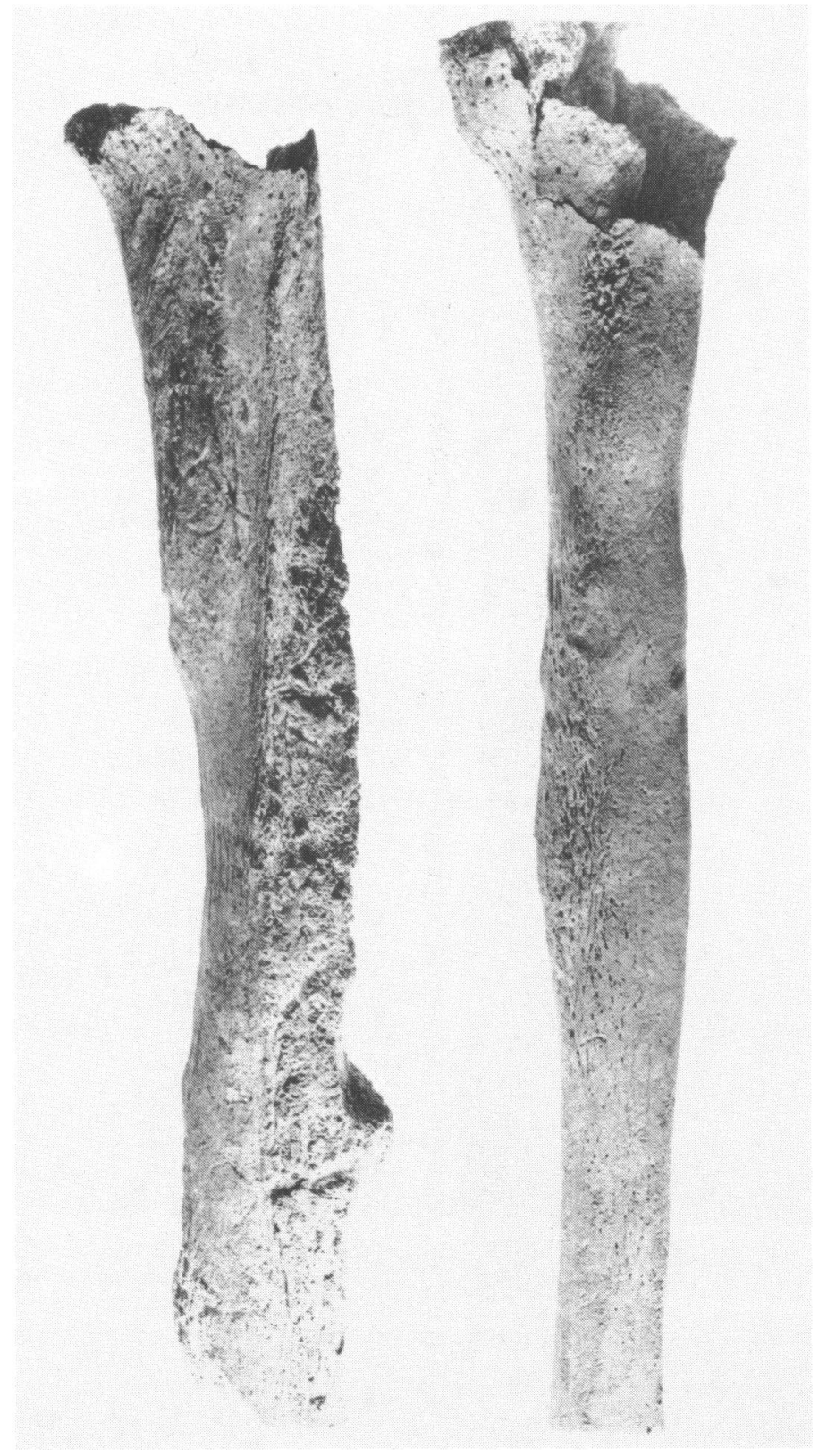

Plate 7a Frontal view of the tibiae of Sk 32. 


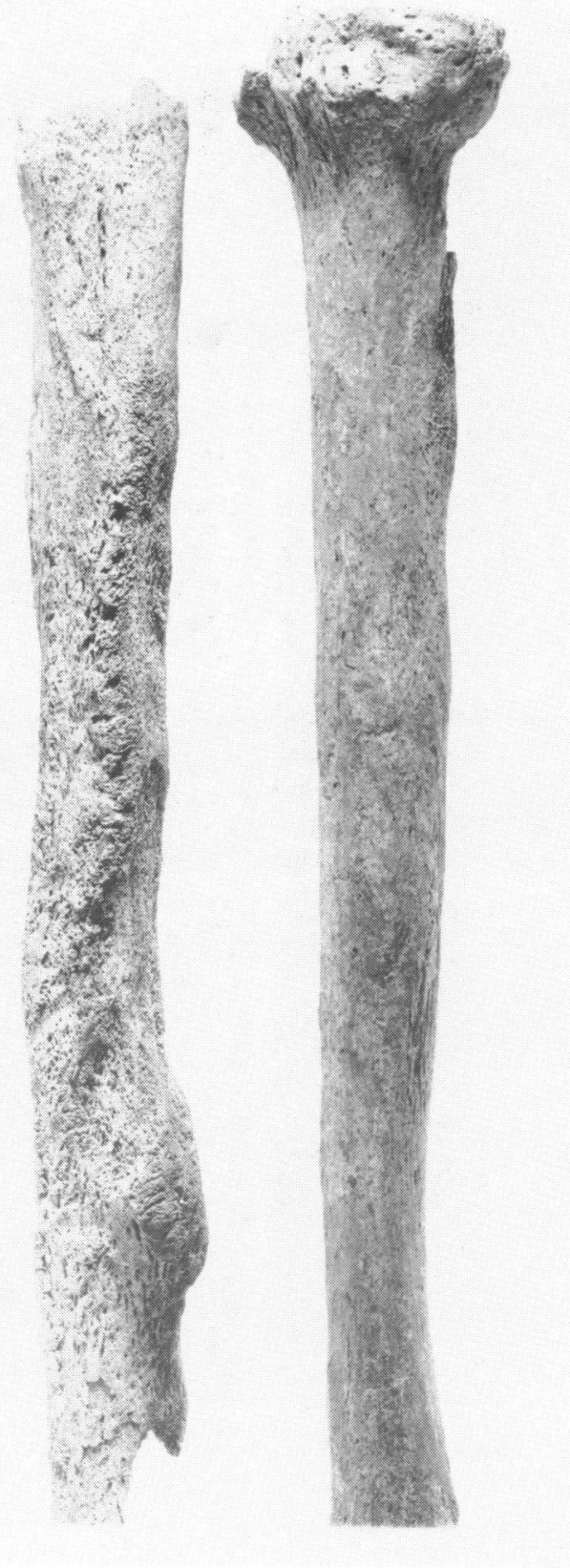

Plate $7 b$ Medial surface of tibiae. 


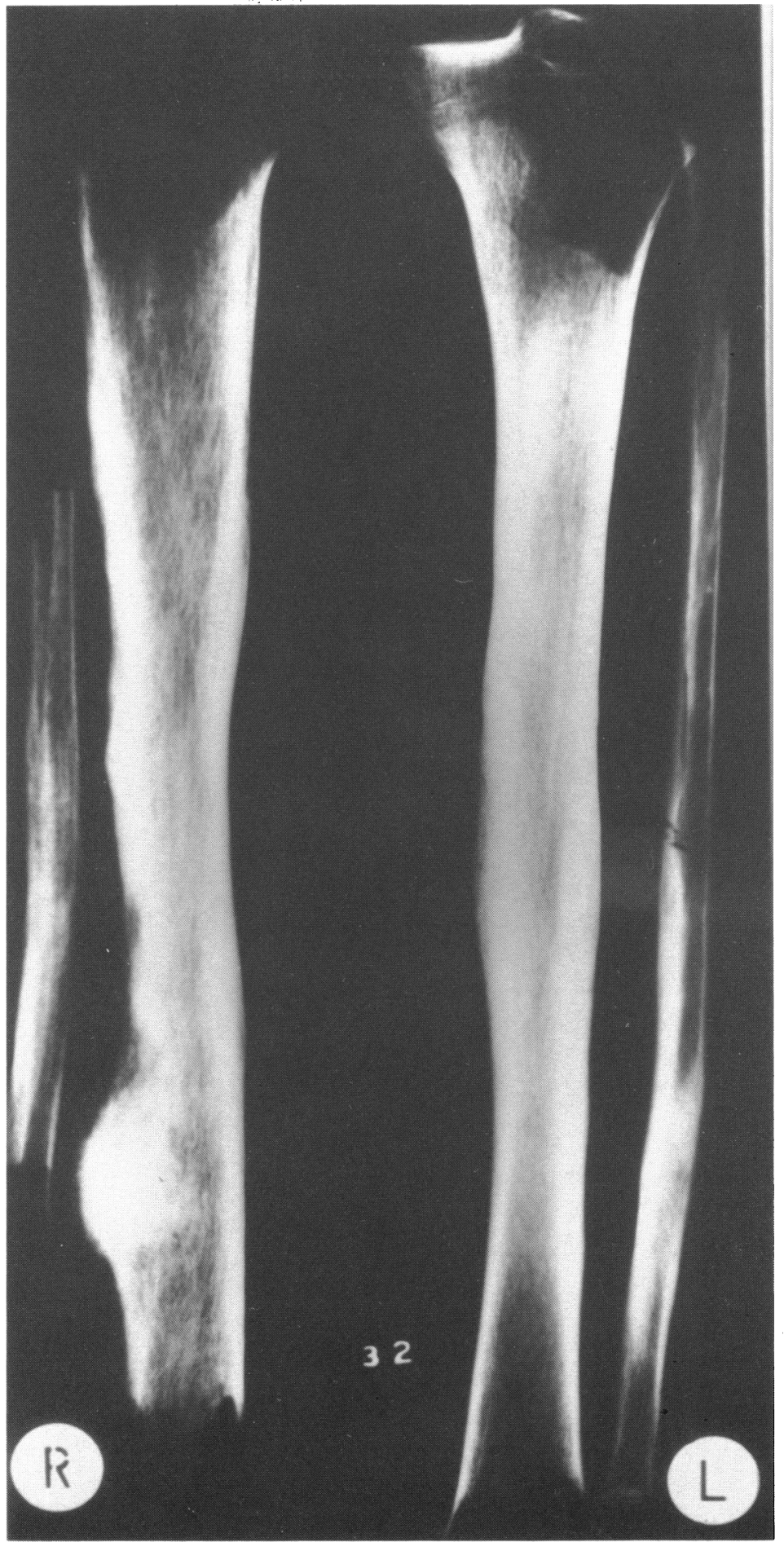

Plate 8 Frontal X-ray projection of tibiae Sk 32.

(The right tibia is rotated $180^{\circ}$.) 


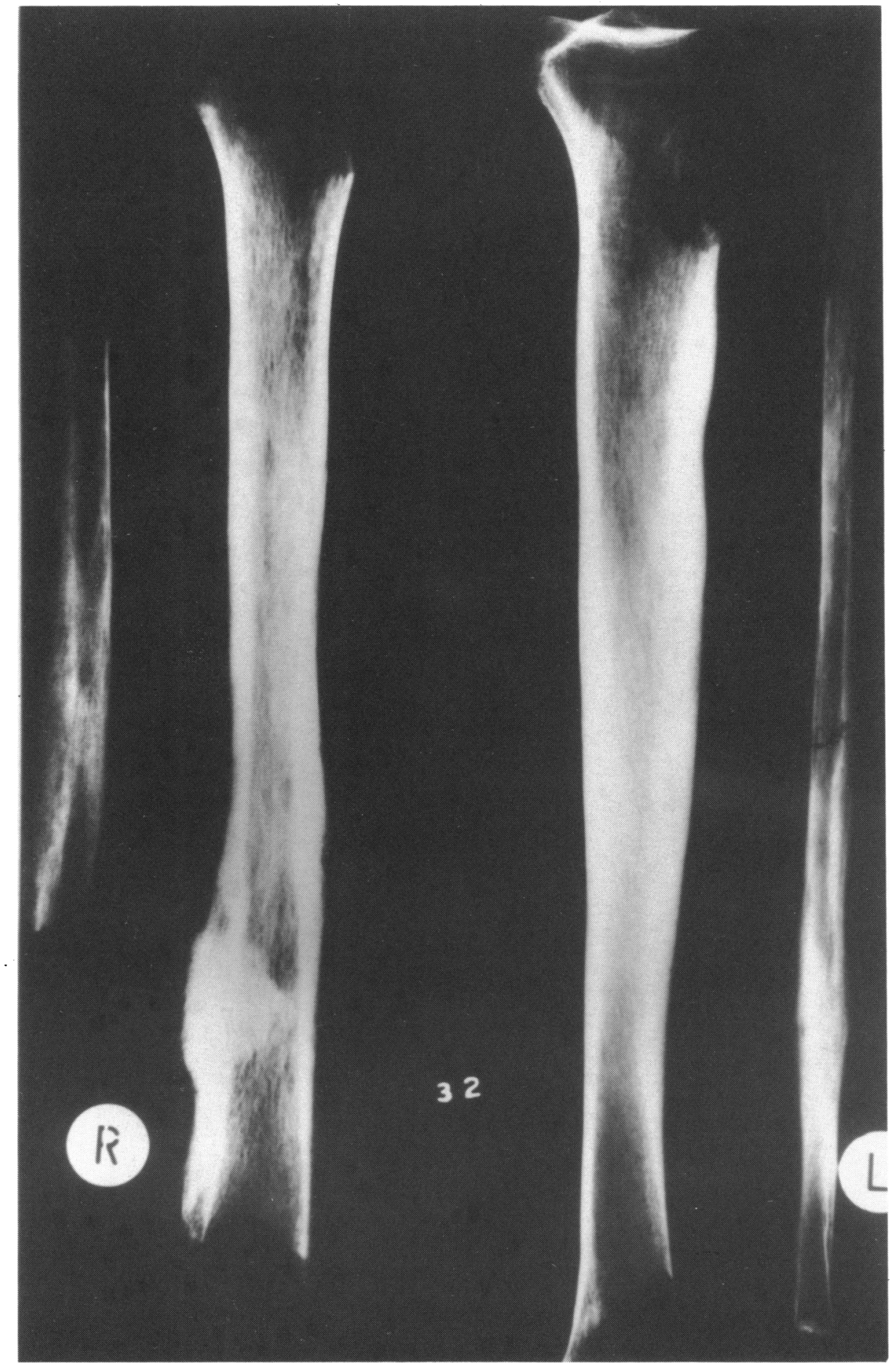

Plate 9 Lateral X-ray projection of tibiae Sk 32. 


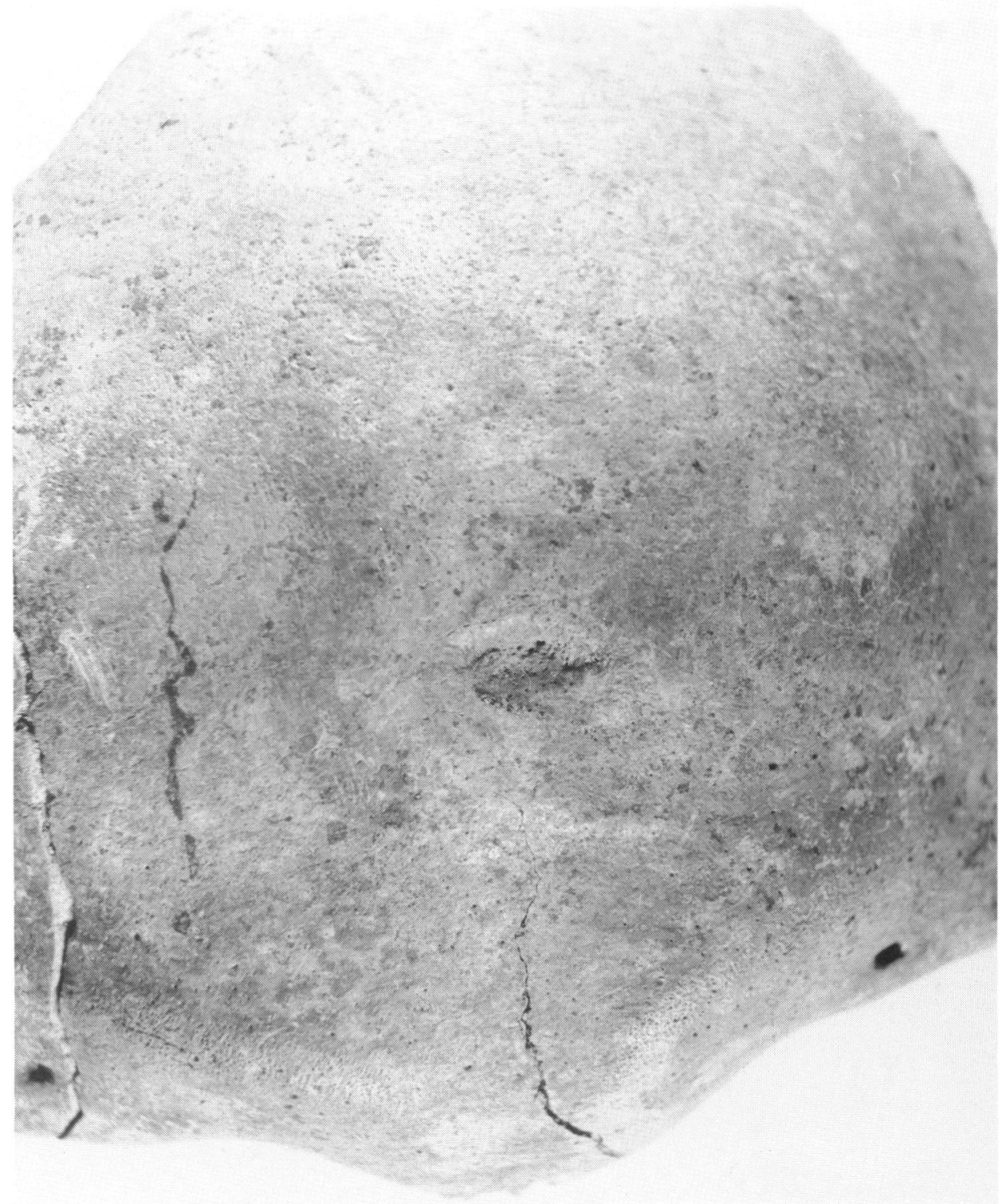

Plate 10 Photograph of the outer surface of the loose skull fragment. 


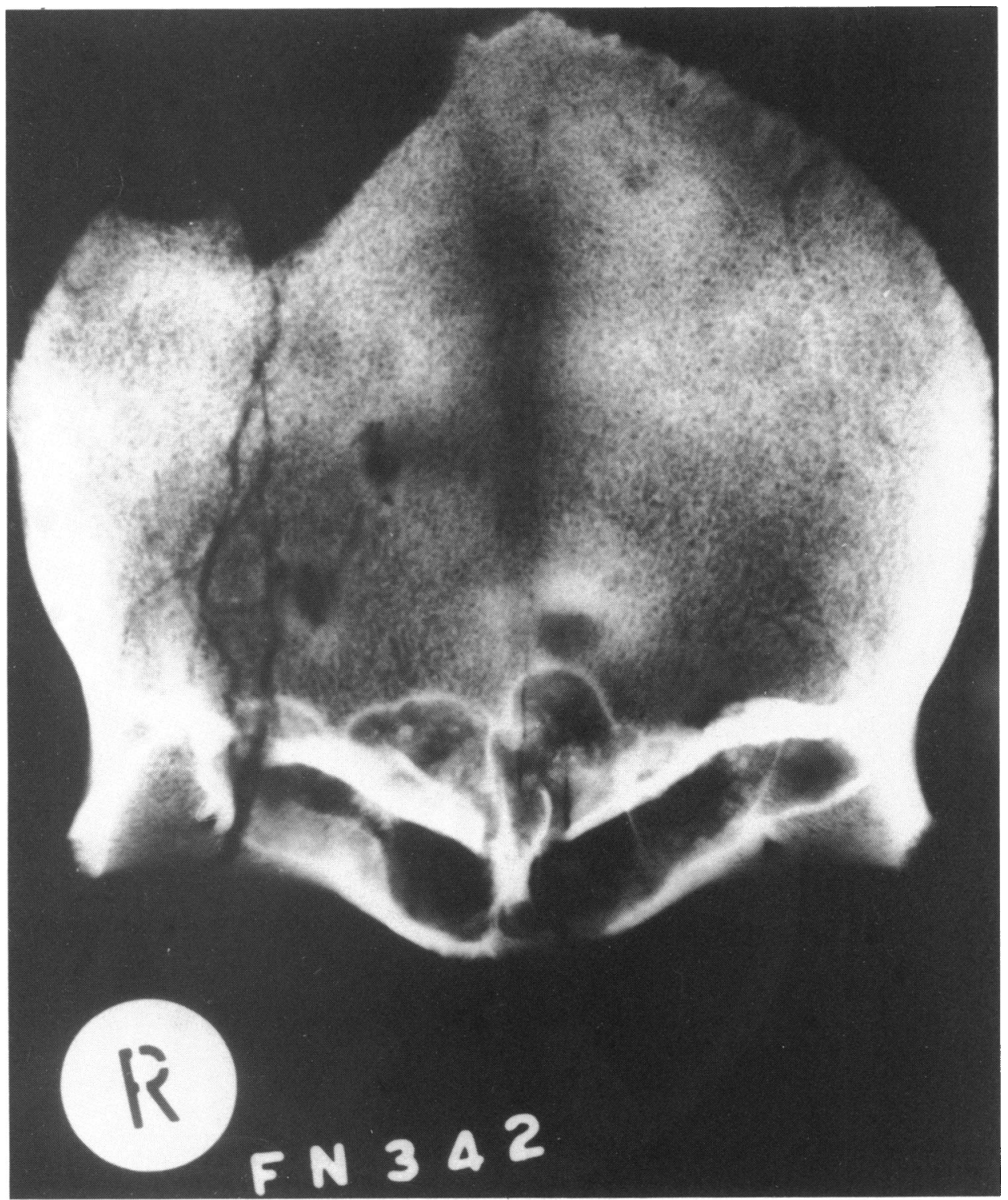

Plate 11 Frontal X-ray projection of the loose skull fragment. 


\section{Suspected endemic syphilis (treponarid) in sixteenth-century Norway}

variable sizes and configurations (gummata?) ${ }^{1,2,3}$ in the middle part of the diaphysis. (Plates 5 and 6)

Fibulae: Right, exhibits swelling of the central diaphysis, more marked on the medial surface. Left, slight localized swelling of the distal diaphysis, confined to the medial surface.

X-ray findings: Right, irregular cortical thickening in the middle part of the shaft.

Ulnae: Right, slight swelling and roughening restricted to the posterior surface of the proximal diaphysis. Slight bowing of both shafts.

$\mathrm{X}$-ray findings: Both show marked curving of the posterior border due to new bone deposition. The endosteal surface is irregular and not well marked.

Vertebrae: Second and third cervical bodies have bony spurs on their ventral, caudal aspects.

$\mathrm{X}$-ray findings: Osteophytes are found on the anterior, inferior margins of the second and third cervical bodies.

Skeleton 32

N 82400

Age:24-27 Sex:Male Height: $178 \mathrm{~cm}$

State of preservation: Quite good. The feet are missing, but the hands are practically complete. The skull, costae, vertebrae, pelvis, right femur, and fibula are fragmentary.

Teeth: $\quad 11,22,31$ and 41 lost post mortem. The remaining teeth are well preserved and exhibit little wear.

Tibiae: Exhibit bilateral swelling. Left, confined to the anterior surface of the central diaphysis, striated, but relatively smooth. Right, much more serious changes, with rugose bone formation on both anterior and posterior surface of the whole diaphysis, causing general deformation of the shaft. Also an osseous node $4.5 \mathrm{~cm}$ in diameter and $0.5 \mathrm{~cm}$ thick on the posterior surface of the distal diaphysis. (Plate 7)

X-ray findings: Left, relatively smooth cortical bone deposition. Right, shows localized sclerotic thickening in the distal part of the posterior diaphysis. There are two small lytic lesions (gummata?) proximal to this node. (Plates 8 and 9)

Fibulae: Left, slight swelling of the distal diaphysis. Right, fragmentary, only mid-shaft present. This is badly swollen with roughening of the anterior border and rugose bone formation along the interosseous border.

$\mathrm{X}$-ray findings: Left, shows new periostal bone deposition. Right, shows

\footnotetext{
${ }^{1}$ Ronald O. Murray and Harold G. Jacobsen, The radiology of skeletal disorders, London, Churchill Livingstone, 1977, pp. 444-461.

${ }^{2}$ H. R. Schinz, W. E. Baensch, E. Friedl, and E. Mehlinger, Roentgen-diagnostics, vol. 1, New York, Grune \& Stratton, 1951, pp. 488-629.

${ }^{3} \mathrm{R}$. Ted Steinbock, Paleopathological diagnosis and interpretation: bone diseases in ancient human populations, Springfield, Illinois, C. C Thomas, 1976, pp. 16, 110-113, 138-142.
} 
T. Anderson, C. Arcini, S. Anda, A. Tangerud, and G. Robertsen

marked thickening and some deformity in the contour of the bone fragment.

Ulnae: Exhibit bilateral swelling on the posterior surface of the diaphyses, more advanced on the left side.

X-ray findings: Both show curving of the posterior border due to new bone formation and thickening of the corticalis.

Loose bone

N 86154

Age: ? Sex: ? Height: ?

Skull: $\quad$ Fragmentary. Frontal bone exhibits a small, circular crater-like lesion in the left side. It does not penetrate the inner table, but has initiated bone thickening around the depression (circumvallate cavitation?). ${ }^{4}$ Three small irregular nonconspicuous lytic areas are found on the inner table. (Plate 10) $\mathrm{X}$-ray findings: Show a sclerotic bone reaction around a $1 \mathrm{~cm}$ circular, lytic lesion. Two other smaller irregular figures surrounded by minimal sclerotic bone reactions are found on the right side of the frontal bone, and a similar figure is found in the left supraorbital region. (Plate 11)

Skeleton 51

N 82422

Age:c.30 Sex:Male Height:173 cm

Excellently preserved. Dens axis is absent (report in preparation). This is otherwise a normal skeleton used as a control.

These bones, as well as all the other human skeletal material from the excavation, are stored at the University Museum in Trondheim.

\section{HARRIS LINES}

We have observed the Harris lines of the X-rayed skeletons and we consider that no significant conclusions can be determined from these.

\section{DIAGNOSIS}

The most obvious pathological change in the three affected skeletons, the swelling and striation of their tibiae, is compatible with a treponemal infection. ${ }^{5,6}$ In our opinion, the changes in the tibiae together with the further pathological evidence from the other long bones and the cervical vertebrae are diagnostic of a treponemal disease. This view is supported by $\mathrm{X}$-ray findings.

\footnotetext{
${ }^{4}$ C. J. Hackett, Diagnostic criteria of syphilis, yaws and treponarid (treponematosis) and of some other diseases in dry bones, Heidelberg, Springer Verlag, 1976, pp. 16-21, 107-112.

${ }^{5}$ Don R. Brothwell and A. T. Sandison (editors), Diseases in antiquity, Springfield, Illinois, C. C Thomas, 1967, pp. 279-294.

6 Don R. Brothwell, Digging up bones, London, Oxford University Press for the British Museum (Natural History), 1981, pp. 134-138.
} 
Suspected endemic syphilis (treponarid) in sixteenth-century Norway

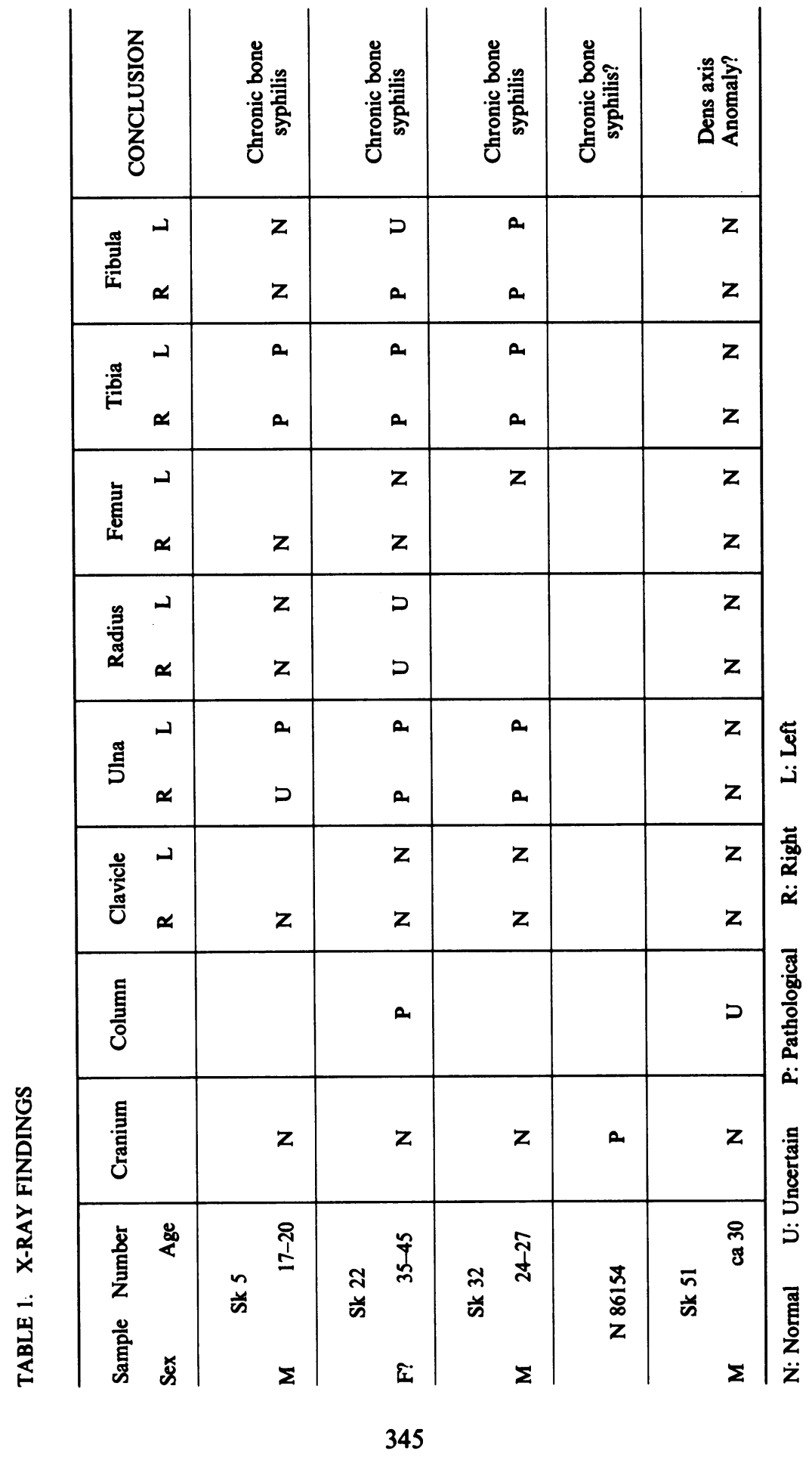




\section{T. Anderson, C. Arcini, S. Anda, A. Tangerud, and G. Robertsen}

\section{DIFFERENTIAL DIAGNOSIS}

Consideration has been given to various differential interpretations. The absence of cloacae or sequestra argues against a non-specific pyogenic infection, as does the bilateral nature of the reaction. The generalized nature of the disease as well as the lack of femoral involvement suggests that it is not Garré's sclerosing osteomyelitis. ${ }^{7}$

Primary neoplastic growths of the bone, such as osteosarcoma and Ewing's sarcoma, are not bilateral phenomena. Multiple bone metastases can be excluded due to their different $\mathrm{X}$-ray appearance, as can histiocytosis $\mathrm{X}$, polyostotic fibrous dysplasia and osteitis deformans (Paget's disease). 1,2

Certain infectious diseases in their early stages may cause a general osteitic reaction before they manifest their more typical characteristics. Tuberculosis, however, is an unlikely diagnosis as there is no evidence of any joint changes and also the tibial shafts are affected rather than the metaphyses. ${ }^{8}$ The right tibia of Skeleton 5 is fifty per cent heavier than a control medieval tibia of similar size (Sk 51). This would argue against osseous tuberculosis, which is typified by bone resorption. The advanced sclerotic bone deposition would also rule out leprosy, because the latter is typified by a mild osteitis or "hazy bone destruction".

The possibility of the diaphyseal swelling being due to a vitamin deficiency was also considered. If rickets had caused the tibial changes, one would also expect a similar reaction in the femora. X-rays have shown the latter to be normal. Scurvy is not a very likely possibility since there is no sign of ante-mortem costal fractures. ${ }^{8}$ Nor have the three skeletons suffered any serious in vivo tooth loss, which would be suggestive of avitaminosis C. ${ }^{10}$

The reported pathology could be caused by one or more until now unknown or unrecognized diseases; however, this possibility does not seem very likely. Thus, we believe that the presented pathological skeletons, although showing varying degrees of osseous involvement, are all suffering from chronic treponemal bone changes.

\section{TREPONEMAL INFECTIONS}

Treponemal infections can occur in four different forms: yaws, pinta, endemic syphilis (treponarid), and venereal syphilis. The first two of these would not be found in Scandinavia, due to their geographical distribution. ${ }^{8,11}$ Therefore, it is safe to assume that the bone changes are the result of syphilis. It is generally thought that the lesions in acquired syphilis (venereal or congenital) and the endemic form are so similar that it may not be possible to differentiate between them. ${ }^{4}$

\section{SYPHILIS - VENEREAL OR ENDEMIC?}

Sclerotic thickening of the tibiae as well as the bony spurs on the cervical vertebrae may be typical of syphilis but cannot help to distinguish between the acquired and the

\footnotetext{
${ }^{7}$ C. Garré, 'Ueber besondere Formen und Folgezustände der akuten infektiösen Osteomyelitis', Beitr. klin. Chir., 1893, 10: 257-276.

${ }^{8}$ Donald J. Ortner and Walter G. J. Putschar, Identification of pathological conditions in human skeletal remains, Washington, Smithsonian Institution Press, 1981, pp. 159-160, 180-181, 197, 272-278.

9 Vilhelm Møller-Christensen, Bone changes in leprosy, Copenhagen, Munksgaard, 1961, p. 16.

${ }^{10}$ Calvin Wells, Bones, bodies and disease, London, Thames \& Hudson, 1964, p. 118.

${ }^{11}$ Keith Manchester, The archaeology of disease, Bradford, University of Bradford, 1983, pp. 45-48.
} 


\section{Suspected endemic syphilis (treponarid) in sixteenth-century Norway}

endemic form. However, venereal syphilis often attacks the skull with typical caries sicca lesions. ${ }^{12,13,14}$ As the skulls of the three reported pathological skeletons are all normal, this may be an indication that we are dealing with an endemic form of syphilis. The absence, in all ninety-five skeletons, of Charcot joints, which can develop in acquired syphilis due to tabes dorsalis, supports the view that an endemic form of syphilis was present. Also, skeleton 5, a juvenile, can hardly have developed bone changes due to venereal syphilis so soon after puberty. It would appear unlikely that the presented skeletons were suffering from congenital syphilis, which is normally recognized by small multiple destructive lesions on the skull, and also by the presence of Hutchinson's teeth. The fact that the skulls are normal, and the absence of any dental stigmata on the very well-preserved teeth, argue against a congenital form of syphilis.

This leads us to the conclusion that the presented skeletons were probably suffering from endemic syphilis. The ulna is reported to be a more common site of infection in endemic than in acquired syphilis. ${ }^{3,8}$ The ulnae of all three skeletons display slight pathological involvement; this appears to be a further indication that our theory is correct. Possibly the loose skull fragment represents a fourth case of syphilis. Yet with only the evidence from a single bone, it could be an osteomyelitic reaction or tuberculosis. Therefore, we feel that we must concentrate on the three reported skeletons, and assess the implications of our findings from these, which represent about three per cent of the skeletal material excavated in 1984.

Although sixty per cent of untreated syphilitics are reported to undergo spontaneous cure, ${ }^{15}$ at least 7-10 per cent of those infected do develop chronic bone changes. ${ }^{3}$ Three of the excavated skeletons show signs of osseous treponemal involvement. If they are representative of the town's inhabitants-which, of course, is an uncertain hypothesis-this would mean that around 21-30 per cent of the population was suffering from syphilis. Such a high rate of infection, if correct, indicates that endemic rather than venereal syphilis was prevalent, as the latter is reported to affect less than ten per cent of a population. ${ }^{3}$

\section{SYPHILIS IN THE EARLY RENAISSANCE}

The dispute over the origin of syphilis in Europe still continues. ${ }^{3,4,8,16}$ However, it is admitted that, from whatever source, the disease spread rapidly across Europe in the years immediately before and after $1500 .{ }^{11,13}$ Except for our report, the only proof for it reaching Norway is literary evidence from Bergen,${ }^{17}$ which was then the capital. From this, it appears that the disease was being treated as early as 1518 , by several named women, mostly of Dutch origin.

\footnotetext{
12 Vilhelm Møller-Christensen, Bogen om Abelholt kloster, Copenhagen, Dansk Videnskaps Forlag, 1958, pp. 193-200.

${ }^{13}$ R. Virchow, 'Ueber die Natur der constitutionell syphilitischen Affectionen', Virchows Arch. path. Anat. Physiol., 1858, 15: 217-336.

${ }^{14}$ R. Virchow, 'Beitrag zur Geschichte der Lues', Derm. Z., 1896, 3: 1-9.

15 World Health Organisation, 'Treponemal infections', WHO Tech. Rep. Ser. 674, 1982, pp. 1-75.

${ }^{16}$ E. H. Hudson, 'Treponematosis in perspective', Bull. Wld. Hlth. Org., 1965, 32: 735-748.

${ }^{17}$ Fr. Grøn, 'Om syphilis's første opptraden i Norge', Tiddsskr. for Den Norske Lageforening, 1912, 10: $417-422$.
} 


\section{"RADESYKEN"}

The next report of probable syphilis in Norway was published some 200 years later, referring to "radesyken", which apparently represented a non-venereal form of the disease. ${ }^{18}$ The symptoms of radesyken were mainly ulcerations of the throat and the nasal area, and sores on the arms and the legs. ${ }^{18}$ Public officials and special radesyke-doctors were instructed to give reports on the disease, which seems to have been prevalent in the rural southwest of Norway where the living conditions during this period were extremely poor. The same disease, but mentioned by other names (Franzoser, Saltflod, Klubba), was frequently reported from other parts of Norway, including the rural districts around Trondheim. ${ }^{18}$

\section{HYGIENIC STANDARD}

Crowded living spaces with low hygienic standards seem to favour the non-venereal spread of syphilis, which therefore may exist in an endemic form. ${ }^{3,4,8,19}$ It has been reported that endemic syphilis tends to disappear as the living conditions improve. ${ }^{19,20}$

\section{LIVING CONDITIONS IN TRONDHEIM}

Trondheim was a very prosperous merchant town in the earlier medieval period, and it was also an important pilgrimage centre for northern Europe. However, the visitation of the plague in 1349, the outbreaks of smallpox in 1359 and 1371, as well as the restrictive trade decree of 1384, caused a great decline in the town's prosperity. Even in the sixteenth century, Trondheim could be described as little more than a village $^{21}$ with about 1200 inhabitants. ${ }^{22}$ Against this background of economic failure with resultant poverty, it is quite safe to envisage a general decline in living conditions.

\section{DATING}

One of the most important aspects of the discovery is the actual date of the skeletal material. Work based on the finds from the graves and the surrounding layers, as well as the stratigraphic relationships themselves has suggested that Sk 32 is slightly earlier than Sk 22. Both are dated to the sixteenth century. Sk 5 appears to be rather younger and must be early seventeenth century. The loose skull fragment, $\mathbf{N} 86154$, was found disturbed in a sixteenth-century trench fill. Its initial burial date must be earlier than that date. Pottery evidence can only date the grave of SK 32 as being later than the fourteenth century and earlier than the seventeenth century. However, it was covered by a layer of burnt wood and clay, which represents the town fire of 1531 and is therefore earlier than this date. Sk 22 is sealed by a layer which lies beneath the 1598 fire layer and can therefore be dated around the middle of the sixteenth century.

Originally, it was thought that none of the burials could be later than 1559 , for it was

\footnotetext{
${ }^{18}$ Stian W. Erichsen, 'Radesyken', ibid., 1964, 22: 1531-1537.

19 E. H. Hudson, 'Endemic syphilis - heir of the syphiloids', Arch. intern. Med., 1961, $108:$ 1-4.

${ }^{20}$ R. R. Willcox, 'International aspects of the venereal diseases and nonvenereal treponematoses', Clin. Obstet. Gynecol., 1975, 18: 207-222.

${ }^{21}$ Frank N. Stagg, The heart of Norway, London, Allen \& Unwin, 1953, p. 70.

22 Grethe A. Blom, Trondheim bys Historie, vol 1, St. Olavs by ca. 1000-1537, Trondheim, F. Bruns, 1956, p. 431 .
} 
then that the church passed into private hands. ${ }^{23}$ However, it would appear that occasional interments still took place in the northern part of the cemetery. Indeed, the grave of Sk 5 actually cuts through the 1598 fire layer and cannot be earlier than the beginning of the seventeenth century. Thus, these skeletons show that syphilis was prevalent in sixteenth- as well as seventeenth-century Trondheim.

\section{ARCHAEOLOGY AND OSTEOLOGY}

The archaeological evidence also suggests a rather impoverished population. Despite very good conditions of preservation, in which not only the wood, but also certain soft tissues, including brains have survived, there are no traces of any coffins from the fifteenth, sixteenth, or seventeenth centuries. This may be related to the fact that we are excavating on the north side of the church, which was regarded as being the least auspicious area in which to be buried, and as such would often be the last resting-place for the poorer sections of the population. Of course, rather than being local inhabitants, the three sufferers may have been sick pilgrims who hàd visited Trondheim in vain.

The osteological evidence, based on the ninety-five skeletons excavated in 1984, has shown that about eighty-five per cent of the population reached adulthood. Males outnumbered females by 7:4 and only twenty-one per cent of the total population lived beyond the age of thirty-five.

\section{ENDEMIC SYPHILIS IN NORWAY?}

The presented evidence suggests that many of the inhabitants of sixteenth-century Trondheim were rather poor and may have been susceptible to infectious diseases, including endemic syphilis. Endemic syphilis is now only prevalent in subtropical regions with warm and arid climates. Yet it must be remembered that previously, similar non-venereal forms of syphilis were reported from other parts of northern Europe, "Sibbens" in Scotland, "Button Scurvy" in Ireland, "Saltfluss" in Sweden, as well as "Radesyken" in Norway. Indeed, some authors consider that endemic syphilis was quite common in pre-Columbian Europe. ${ }^{24}$ In view of this evidence, there appears to be no reason why an impoverished section of a sixteenth-century Norwegian population, displaying syphilitic bone changes, should not have been suffering from treponarid infection.

\section{CONCLUSION}

We have drawn our conclusion from the observed pathology in the reported skeletons, supported by X-rays. Although Hackett, ${ }^{4}$ a leading contemporary authority on syphilis, considers the documented changes as being on trial rather than diagnostic of treponemal infection, we still maintain that the reported pathology, combined with the apparent incidence of the lesions, suggests that we are dealing with an endemic form of syphilis. The fact that none of the 260 skeletons excavated in 1985 from the twelfth to the fifteenth century displays the same pathology may indicate that the disease was not present in Trondheim until the sixteenth century.

${ }^{23}$ Norsk Rigs-register I, 269.

${ }^{24}$ R. R. Willcox, 'The treponemal evolution', Trans. St John's Derm. Soc, 1972, 58: 21-37. 
T. Anderson, C. Arcini, S. Anda, A. Tangerud, and G. Robertsen

As far as we know, endemic syphilis, although suspected of being present, has not actually been reported from this period in any part of Europe. Consequently, if our conclusion is correct, this finding is of great importance. It is to be hoped that further osteological and medical studies, including work on the preserved brains and analysis of soil samples, will tell us even more about the way in which people lived and died in later-medieval Trondheim. 